\title{
Effect of Temperature and Electrolytic Concentration on Density and Viscosity of Ethanol-Water Mixed Solvent Systems
}

\section{Anis Ahmed Sheikh ${ }^{1 *}$, Syed U.K. Asema ${ }^{1}$, Mohamad Asif ${ }^{1}$, Shaukat Patel ${ }^{2}$}

${ }^{1}$ Post Graduate and Research Centre, Maulana Azad College of Arts,Science and Commerce Aurangabad, Maharashtra, India

${ }^{2}$ Department of Industrial Chemistry, Adarsh Mahavidyalay, Omerga, Maharashtra, India

*Corresponding Author email id : anisahmed8azad@gmail.com

\begin{abstract}
The density and Viscosity of Ethanol-Water mixed solvent systems (5\%, 10\%, 20\%,40\% v/v ) has been determined at 298,303,308 and $313 \mathrm{~K}$. The same parameters has been determined for the KCl-Ethanol-Water mixture $(2 \%, 4 \%, 6 \%, 8 \%, 10 \% \mathrm{w} / \mathrm{v})$ The results obtained from these determinations were discussed. The effect of temperature and $\mathrm{KCl}$ electrolyte on density and viscosity of mixed solvent systems and mixture has been studied. The increase in temperature of mixed solvent system results in decrease in density and Viscosity. But with the addition of $\mathrm{KCl}$ electrolyte in mixed solvent system results in increase in density and viscosity at constant temperature but the same parameters decrease when temperature increases. The variation of these parameters is due to solute-solvent and solvent-solvent interaction.
\end{abstract}

Keywords : Ethanol-Water, KCl Electrolyte, Density, Viscosity

\section{INTRODUCTION}

The density and viscosity of solution plays an important role in transportation of minerals and other vital components from one place to other in human and plant body. These are important physicochemical properties which are useful in understanding the nature of solution. Maximum biochemical process in human and plant body takes place in liquid media which has to be present in sufficient amount. Therefore the transport of the liquid from one place to other place depends upon the nature of liquid. The density of liquid is the ratio of mass and volume. As the mass increases the density also increases. This is the reason now a day maximum patients are suffering from cardiac diseases ${ }^{1}$ because of deposition of fats in body. The viscosity of liquid is resistance to flow which is due to internal friction of layers and also impurities in liquids. But the temperature of liquid decreases the viscosity of liquid. Anis Ahmed Sheikh et.al has proposed that temperature and viscosity are inversely proportion to each other. ${ }^{2}$ The electrolyte in mixed solvent system also plays an important role for deciding the density and viscosity of solvents. ${ }^{3}$ With change in electrolytic concentration like $\mathrm{KCl}$ and $\mathrm{NaCl}$ the density and viscosity also changes. It is due to solute-solvent interaction. Ummul Khair Asema et.al has proposed the effect of sodium chloride electrolyte on density and viscosity of ethanol-water mixed solvent systems and concluded that the increase in viscosity with electrolyte is due to solutesolvent interaction. ${ }^{4}$ From our previous investigation of effect of electrolyte on density and viscosity of ethanol water mixed solvent system ${ }^{5-9}$ we have now determined the viscosity and density of ethanol-water mixed solvent system and ethanol-water-KCl 
mixtures at different temperature and the results are discussed.

\section{EXPERIMENTAL}

All the chemicals were AR grade of SD-fine and Sigma Aldrich brand. The refluxed ethanol was used. Doubly distilled water used for preparation of mixed solutions and mixtures. The density and viscosity parameters were determined by Pyknometer and Ostwald's Viscometer.

The different sets of ethanol-water mixed solvents (5\%, $10 \%, 20 \%, 40 \%)$ were prepared by adding $5,10,20$ and $40 \mathrm{ml}$ ethanol in $100 \mathrm{ml}$ water $(\mathrm{v} / \mathrm{v})$. All the sets were kept in thermostat to attain the uniform temperature. The density of each mixed solvent set was determined by Pyknometer at 298,303,308 and $313 \mathrm{~K}$ and results are tabulated (table1).The viscosity of these sets were determined by Ostwald's Viscometer by flow time method using formula and the results are tabulated (table 2).To each set of mixed solvent system $2,4,6,8$ and 10 gram $\mathrm{KCl}$ was added to make $2 \%, 4 \%, 6 \% 8 \%$ and $10 \%$ mixture and kept in thermostat.(w/v).Then the density and viscosity of each mixture was determined at said temperatures and results obtained are tabulated in table 3 and 4 respectively.

\section{Calculation:}

The density of each set of mixed solvent system and mixtures was determined by using the following formula.

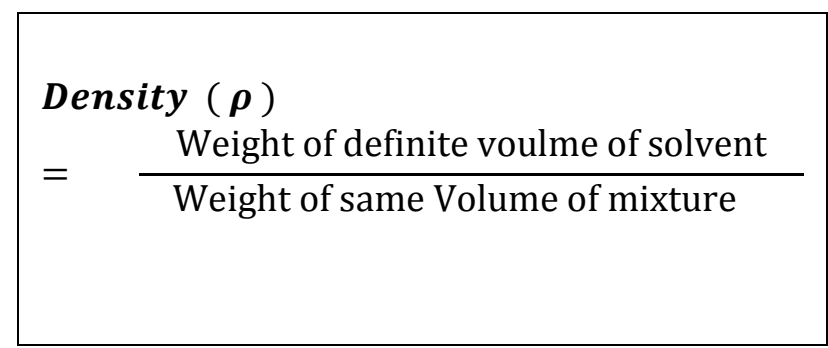

$$
\operatorname{Viscosity}(\eta 2)=\frac{t 2}{t 1} \cdot \frac{\rho 2}{\rho 1} \cdot \eta 1
$$

Where

$$
\begin{aligned}
& \eta_{2}=\text { Viscosity of mixed mixture } \\
& t_{1}=\text { Flow time for mixed solvents } \\
& t_{2}=\text { Flow time for mixture } \\
& \rho_{1}=\text { Density of mixed solvents } \\
& \rho_{2}=\text { Density of mixed mixture } \\
& \eta_{1}=\text { Viscosity of mixed solvents }
\end{aligned}
$$

From the above formulae the density and viscosity of all the sets of mixed solvent systems and mixtures were determined.

Table 1. Density of Mixed solvent systems at different Temperatures

\begin{tabular}{|l|l|l|l|l|l|}
\hline $\begin{array}{l}\text { Mixed Solvents } \\
\text { Systems } \\
\left(\mathrm{EtOH}+\mathrm{H}_{2} \mathrm{O}\right) \downarrow\end{array}$ & $\begin{array}{l}\mathrm{T}(\mathrm{K}) \\
\rightarrow\end{array}$ & 298 & 303 & 308 & 312 \\
\hline $5 \%$ & 0.987 & 0.977 & 0.970 & 0.824 \\
\hline $10 \%$ & 0.998 & 0.989 & 0.977 & 0.959 \\
\hline $20 \%$ & 1.003 & 0.998 & 0.987 & 0.976 \\
\hline $40 \%$ & 1.009 & 1.001 & 0.997 & 0.988 \\
\hline
\end{tabular}


Table 2. Viscosity of Mixed Solvent Systems at different Temperatures

\begin{tabular}{|c|c|c|c|c|c|}
\hline $\begin{array}{c}\text { Mixtures } \\
\left(\mathrm{EtOH}+\mathrm{H}_{2} \mathrm{O}\right) \downarrow\end{array}$ & $\begin{array}{c}\mathrm{T}(\mathrm{K}) \\
\rightarrow\end{array}$ & 298 & 303 & 308 & 312 \\
\hline $5 \%$ & 0.0096 & 0.0080 & 0.0034 & 0.0063 \\
\hline $10 \%$ & 0.0109 & 0.0103 & 0.0072 & 0.0068 \\
\hline $20 \%$ & 0.0140 & 0.0121 & 0.0096 & 0.0080 \\
\hline $40 \%$ & 0.0185 & 0.0171 & 0.0138 & 0.0113 \\
\hline
\end{tabular}

Table 3. Density of Mixtures in different solvent systems at different temperatures

\begin{tabular}{|c|c|c|c|c|c|c|}
\hline $\begin{array}{c}\mathrm{EtOH}+ \\
\mathrm{H}_{2} \mathrm{O}\end{array}$ & $\begin{array}{c}\mathrm{EtOH}+\mathrm{H}_{2} \mathrm{O}+ \\
\mathrm{KCl} \downarrow\end{array}$ & $\begin{array}{c}\mathrm{T}(\mathrm{K}) \\
\rightarrow\end{array}$ & 298 & 303 & 308 & 312 \\
\hline \multirow{5}{*}{$5 \%$} & \multicolumn{2}{|l|}{$2 \%$} & 0.877 & 0.850 & 0.847 & 0.843 \\
\hline & \multicolumn{2}{|l|}{$4 \%$} & 0.887 & 0.862 & 0.860 & 0.850 \\
\hline & \multicolumn{2}{|l|}{$6 \%$} & 0.898 & 0.871 & 0.866 & 0.857 \\
\hline & \multicolumn{2}{|l|}{$8 \%$} & 0.905 & 0.884 & 0.873 & 0.863 \\
\hline & \multicolumn{2}{|l|}{$10 \%$} & 0.910 & 0.892 & 0.888 & 0.872 \\
\hline \multirow{5}{*}{$10 \%$} & \multicolumn{2}{|l|}{$2 \%$} & 0.809 & 0.804 & 0.801 & 0.791 \\
\hline & \multicolumn{2}{|l|}{$4 \%$} & 0.818 & 0.810 & 0.807 & 0.803 \\
\hline & \multicolumn{2}{|l|}{$6 \%$} & 0.825 & 0.819 & 0.813 & 0.809 \\
\hline & \multicolumn{2}{|l|}{$8 \%$} & 0.866 & 0.875 & 0.822 & 0.811 \\
\hline & \multicolumn{2}{|l|}{$10 \%$} & 0.893 & 0.877 & 0.841 & 0.824 \\
\hline \multirow{5}{*}{$20 \%$} & \multicolumn{2}{|l|}{$2 \%$} & 0.842 & 0.816 & 0.810 & 0.806 \\
\hline & \multicolumn{2}{|l|}{$4 \%$} & 0.853 & 0.819 & 0.813 & 0.810 \\
\hline & \multicolumn{2}{|l|}{$6 \%$} & 0.830 & 0.820 & 0.815 & 0.812 \\
\hline & \multicolumn{2}{|l|}{$8 \%$} & 0.869 & 0.822 & 0.820 & 0.814 \\
\hline & \multicolumn{2}{|l|}{$10 \%$} & 0.872 & 0.826 & 0.823 & 0.817 \\
\hline \multirow{5}{*}{$40 \%$} & \multicolumn{2}{|l|}{$2 \%$} & 0.820 & 0.815 & 0.812 & 0.810 \\
\hline & \multicolumn{2}{|l|}{$4 \%$} & 0.843 & 0.820 & 0.819 & 0.815 \\
\hline & \multicolumn{2}{|l|}{$6 \%$} & 0.855 & 0.829 & 0.26 & 0.823 \\
\hline & \multicolumn{2}{|l|}{$8 \%$} & 0.873 & 0.841 & 0.832 & 0.831 \\
\hline & \multicolumn{2}{|l|}{$10 \%$} & 0.878 & 0.857 & 0.848 & 0.843 \\
\hline
\end{tabular}


Table 4. Viscosity (in poise) of Mixtures in different solvent systems at different temperatures

\begin{tabular}{|c|c|c|c|c|c|c|}
\hline $\begin{array}{c}\mathrm{EtOH}+ \\
\mathrm{H}_{2} \mathrm{O}\end{array}$ & $\begin{array}{c}\mathrm{EtOH}+\mathrm{H}_{2} \mathrm{O}+ \\
\mathrm{KCl} \downarrow\end{array}$ & $\begin{array}{c}\mathrm{T}(\mathrm{K}) \\
\rightarrow\end{array}$ & 298 & 303 & 308 & 312 \\
\hline \multirow{5}{*}{$5 \%$} & \multicolumn{2}{|l|}{$2 \%$} & 0.0073 & 0.0072 & 0.0071 & 0.0067 \\
\hline & \multicolumn{2}{|l|}{$4 \%$} & 0.0082 & 0.0081 & 0.0074 & 0.0071 \\
\hline & \multicolumn{2}{|l|}{$6 \%$} & 0.0085 & 0.0084 & 0.0083 & 0.0077 \\
\hline & \multicolumn{2}{|l|}{$8 \%$} & 0.0087 & 0.0085 & 0.0084 & 0.0079 \\
\hline & \multicolumn{2}{|l|}{$10 \%$} & 0.0090 & 0.0089 & 0.0087 & 0.0083 \\
\hline \multirow{5}{*}{$10 \%$} & \multicolumn{2}{|l|}{$2 \%$} & 0.0082 & 0.0080 & 0.0078 & 0.0074 \\
\hline & \multicolumn{2}{|l|}{$4 \%$} & 0.0083 & 0.0082 & 0.0080 & 0.0077 \\
\hline & \multicolumn{2}{|l|}{$6 \%$} & 0.0094 & 0.0093 & 0.0090 & 0.0079 \\
\hline & \multicolumn{2}{|l|}{$8 \%$} & 0.0096 & 0.0095 & 0.0099 & 0.0083 \\
\hline & \multicolumn{2}{|l|}{$10 \%$} & 0.0099 & 0.0097 & 0.0102 & 0.0094 \\
\hline \multirow{5}{*}{$20 \%$} & \multicolumn{2}{|l|}{$2 \%$} & 0.0080 & 0.0098 & 0.0088 & 0.0074 \\
\hline & \multicolumn{2}{|l|}{$4 \%$} & 0.0106 & 0.0104 & 0.0097 & 0.0095 \\
\hline & \multicolumn{2}{|l|}{$6 \%$} & 0.0109 & 0.0108 & 0.0105 & 0.0103 \\
\hline & \multicolumn{2}{|l|}{$8 \%$} & 0.0111 & 0.0109 & 0.0107 & 0.0105 \\
\hline & \multicolumn{2}{|l|}{$10 \%$} & 0.0115 & 0.0110 & 0.0109 & 0.0106 \\
\hline \multirow{5}{*}{$40 \%$} & \multicolumn{2}{|l|}{$2 \%$} & 0.0147 & 0.0138 & 0.0134 & 0.0128 \\
\hline & \multicolumn{2}{|l|}{$4 \%$} & 0.0149 & 0.0141 & 0.0137 & 0.0135 \\
\hline & \multicolumn{2}{|l|}{$6 \%$} & 0.1053 & 0.0144 & 0.0140 & 0.0139 \\
\hline & \multicolumn{2}{|l|}{$8 \%$} & 0.0157 & 0.0151 & 0.0143 & 0.0141 \\
\hline & \multicolumn{2}{|l|}{$10 \%$} & 0.0159 & 0.0157 & 0.0147 & 0.0145 \\
\hline
\end{tabular}

\section{III.CONCLUSION}

From our investigation it is revealed that the density of mixed solvent system ( $5 \%$ to $40 \%)$ and mixtures ( $2 \%$ to $10 \%$ ) for all sets decreases as the temperature increases. But the same parameter increases at constant temperature (Table No $1 \& 3$ ). Similarly the viscosity of mixed solvent system (5\% to $40 \%$ ) and mixtures (2\% to $10 \%)$ for all sets also decreases as the temperature increases.(table No. $2 \& 4$ ). This variation is due to solvent-solvent and solute-solute interaction. From this investigation we are going to study the effect of electrolytic concentration on density and viscosity for other solutes and solvents.

\section{REFERENCES}

[1]. Sironi AM, Petz R, De Marchi D, Buzzigoli E, Ciociaro D, Positano V, Lombardi M, Ferrannini E, Gastaldelli A. Impact of increased visceral and cardiac fat on cardiometabolic risk and disease. Diabet Med. 2012 May;29(5),622-627.

[2]. Mohamad Asif, Sayyad Sultan Kasim1, Shahana Parveen2 \& Anis Ahmed Sheikh* Effect of 
Electrolytic Concentration on Density and Viscosity of Ethanol-Water Mixed Solvent Systems. International Journal of Chemical Engineering Research. 2016, 8,(1) 47-50.

[3]. Hai- Lang Zhang, Viscosity and density of $\mathrm{H} 2 \mathrm{O}$ $+\mathrm{NaCl}+\mathrm{CaCl} 2$ and $\mathrm{H} 2 \mathrm{O}+\mathrm{KCl}+\mathrm{CaCl} 2$ at 298.15 K. J.Chem.Eng.Data 1997,42(3), 526-530

[4]. Syed Ummul Khair Asema, Mohd. Asif, Pathan Arif Ali Khan, Anis Ahmed Shaikh* Effects of Concentration on viscometric study of the Sodium Chloride in Ethanol-Water Mixed System. Journal of Medicinal Chemistry and Drug Discovery, February 2016 ,2 (1) 361-365.

[5]. Anis Ahmed Sheikh, Pathan Arif Ali Khan, Ummul Khair Asema, Mohamad Asif. Effect of Metformin drug on density and viscosity of ethanol-water mixed solvent

[6]. systems at $299.5 \mathrm{~K}$. Journal of Medicinal Chemistry and Drug Discovery. 2017, 03 (02) 223-227.

[7]. Ummul Khair Asema, Mohamad Asif, Prashant D. Netankar, Anis Ahmed Sheikh. Study of Effect of $\mathrm{KCl}$ Concentration on Density and Viscosity of Ethanol-Water Mixed Solvent Systems at $298.5 \mathrm{~K}$. International Journal of Research in Chemistry and Environment. 2017, 07, (1) $14-16$.

[8]. Anis Ahmed Sheikh , Mohamad Asif ,Mohammed Juned, Ummul Khair Asema Study of Partition Coefficient, Strength, and Association of Phthallic Acid in Immiscible Liqiuids. International Journal of Chemical Engineering Research. 2016, 8, (1) 39-45.

[9]. Physical Chemistry, Robert J. Silbey and Robert A Alberty, 2002, John Wiley and sons, pp 650742

[10]. Physical Chemistry of Polyelectrolyte solutions by: Mitsuru Nagasawa, Stuart a. rice, Aaron R. Dinner John Wiley \& Sons 2015, pp 193-241.

\section{Cite this article as :}

Anis Ahmed Sheikh, Syed U.K. Asema, Mohamad Asif, Shaukat Patel, "Effect of Temperature and Electrolytic Concentration on Density and Viscosity of Ethanol-Water Mixed Solvent Systems", International Journal of Scientific Research in Science and Technology (IJSRST), Online ISSN : 2395-602X, Print ISSN : 2395-6011, Volume 6 Issue 6, pp. 01-05, November-December 2019. Available at doi : $\quad$ https://doi.org/10.32628/IJSRST196525 Journal URL : http://ijsrst.com/IJSRST196525 